\title{
The Metabolism of Phenylmercury by the Rat
}

\author{
By J. W. DANIEL, J. C. GAGE* and P. A. LEFEVRE \\ Imperial Chemical Industries Limited, Industrial Hygiene Research Laboratories, \\ Alderley Park, Cheshire SK10 4TJ, U.K.
}

(Received 2 May 1972)

\begin{abstract}
The metabolism of $\left[\mathrm{U}-{ }^{14} \mathrm{C}\right]$ phenylmercury acetate was studied in the rat. After a single subcutaneous dose a small proportion is excreted unchanged in urine, and a larger amount in bile with some resorption from the gut. The greater part of the dose is broken down in the tissues to yield inorganic mercury which is excreted mainly in faeces, and conjugates of phenol and quinol are excreted in urine. In experiments in vitro phenylmercury is broken down by liver homogenates to release inorganic mercury and benzene; this reaction is effected by the soluble, but not the microsomal, fraction and does not require NADPH or NADH. No elemental mercury is formed under these conditions. It is probable that this reaction occurs in vivo and the benzene produced is rapidly converted into phenol and quinol by microsomal enzymes.
\end{abstract}

The rapid release of inorganic mercury from phenylmercury in the body has been demonstrated by Miller et al. (1960) and by Gage (1964), using analytical methods capable of distinguishing between organic and inorganic mercury. The same conclusion may be reached from other investigations (Friberg et al., 1957; Swensson et al., 1959; Ulfvarson, 1962; Berlin \& Ullberg, 1963; Ellis \& Fang, 1967) which have shown that the administration of phenylmercury or inorganic mercury labelled with ${ }^{203} \mathrm{Hg}$ to animals leads to a similar distribution of radioactivity in the tissues and excreta. Gage \& Swan (1961) have suggested that this rapid metabolism of phenylmercury is responsible for its failure to produce the severe neurotoxic effects characteristic of methylmercury, which is much more stable in the body. A similar hypothesis has been proposed to account for the absence of such effects with methoxyethylmercury (Daniel et al., 1971).

\section{Materials and Methods}

\section{Preparative methods}

Synthesis of $\left[U_{-}{ }^{14} C\right]$ phenylmercury acetate. [U-1 $\left.{ }^{14} \mathrm{C}\right]$ Benzene $(5 \mu \mathrm{mol})$ (The Radiochemical Centre, Amersham, Bucks., U.K.) was diluted with carrier benzene $(2 \mathrm{ml})$ and added to a solution of mercuric acetate $(25 \mathrm{mmol}$ in $20 \mathrm{ml}$ of acetic acid). Then $\mathrm{HClO}_{4}(60 \%, 0.2 \mathrm{ml})$ was added and the suspension was stirred at $55^{\circ} \mathrm{C}$ for $9 \mathrm{~h}$. The solution was evaporated to dryness under reduced pressure and the residue was extracted three times with $30 \mathrm{ml}$ portions

* Present address: Department of Hygiene, University of Lund, Box 2009, 22002 Lund 2, Sweden. of benzene at $50^{\circ} \mathrm{C}$. The combined extracts were evaporated to dryness and the residue was extracted with $50 \mathrm{ml}$ of acetone. The acetone extract was evaporated and the residue recrystallized from methanol. The product, m.p. $150-152^{\circ} \mathrm{C}$, specific radioactivity $22.9 \mu \mathrm{Ci} / \mathrm{mmol}$ was obtained in $19 \%$ yield. T.1.c. on silica gel HR plates (E. Merck A.G., Darmstadt, Germany) with methanol-acetic acid $(15: 1, v / v)$ as eluent, showed a single radioactive component of $R_{F} 0.76$, identical with that of an authentic sample.

Synthesis of o-hydroxyphenylmercury bromide. Mercuric acetate $(0.05 \mathrm{~mol})$ was added with stirring over a period of $15 \mathrm{~min}$ to phenol $(0.1 \mathrm{~mol})$ maintained at $120^{\circ} \mathrm{C}$, and the melt was heated for a further $5 \mathrm{~min}$. The melt was dissolved in boiling water and $\mathrm{KBr}$ $(0.1 \mathrm{~mol})$ in $50 \mathrm{ml}$ of water was added. The mixture was filtered hot and the filtrate yielded colourless crystals on cooling. Recrystallization from water gave a product with m.p. $136-137^{\circ} \mathrm{C}$ (Found: $\mathrm{C}, 19.2$; $\mathrm{H}, 1.5 ; \mathrm{Br}, 22.3$. Calc. for $\mathrm{C}_{6} \mathrm{H}_{5} \mathrm{OBrHg} ; \mathrm{C}, 19.7 ; \mathrm{H}$, $1.4 ; \mathrm{Br}, 22.0 \%$ ). Analysis by n.m.r. confirmed that the hydroxyl group was in the o-position.

Synthesis of p-hydroxyphenylmercury chloride. $p$-Aminophenol $(0.05 \mathrm{~mol})$ was diazotized and added to a solution of mercuric chloride $(0.05 \mathrm{~mol})$ in $15 \mathrm{ml}$ of conc. $\mathrm{HCl}$. The precipitate was collected by filtration, washed and dried, suspended in $20 \mathrm{ml}$ of ethanol with stirring and $1 \mathrm{~g}$ of freshly prepared copper powder was added. Stirring was continued for $24 \mathrm{~h}$, then the ethanol was evaporated and the residue extracted with acetone in a Soxhlet apparatus. The acetone extract was evaporated to dryness and the residue recrystallized from aqueous ethanol and from acetone. The product had m.p. $215-220^{\circ} \mathrm{C}$ 
(decomp.). Analysis by n.m.r. confirmed that the hydroxyl group was in the p-position.

\section{General methods}

Animal experiments. Male albino Wistar rats (180$220 \mathrm{~g}$ ) of the Alderley Park specific-pathogen-free strain were injected subcutaneously with a solution of $\left[\mathrm{U}-{ }^{14} \mathrm{C}\right]$ phenylmercury acetate in aq. $20 \%(\mathrm{v} / \mathrm{v})$ ethanol. Animals were then transferred to metabolism cages which permitted the collection of urine and faeces, and in some experiments the radioactivity in expired air was measured. The bile duct was cannulated in three rats that had been injected with [U-14 C]phenylmercury acetate and bile was collected for 24 and $48 \mathrm{~h}$. This experiment was repeated on a further three rats at intervals of 72 and $96 \mathrm{~h}$. Throughout the period of collection animals were provided with water containing glucose $(1 \%)$ and $\mathrm{NaCl}(0.9 \%)$.

Separation of radioactive metabolites from urine. Urine from 20 rats dosed with $\left[\mathrm{U}-{ }^{14} \mathrm{C}\right]$ phenylmercury acetate was collected for $48 \mathrm{~h}$ and, after acidification with $\mathrm{H}_{2} \mathrm{SO}_{4}$ to $0.5 \mathrm{M}$, was boiled under reflux for $1 \mathrm{~h}$ and steam-distilled. The distillate was extracted with ether and the extract was dried with anhydrous $\mathrm{Na}_{2} \mathrm{SO}_{4}$ and evaporated to a small volume. The extract was examined by g.l.c. with a Pye Series 104 model 64 apparatus by using $\mathrm{N}_{2}$ at $50 \mathrm{ml} / \mathrm{min}$, and either a $5 \mathrm{ft} \times \frac{1}{4}$ in $(1.5 \mathrm{~m} \times 6.5 \mathrm{~mm})$ column of diethylene glycol succinate $(5 \%, \mathrm{w} / \mathrm{w})$ on Chromosorb W (acid washed, silicone treated) at $150^{\circ} \mathrm{C}$, or a $5 \mathrm{ft} \times 4$ in $(1.5 \mathrm{~m} \times 6.5 \mathrm{~mm})$ column of silicone E-301 $(5 \%, w / w)$ on the same support at $90^{\circ} \mathrm{C}$.

The extract was also examined by t.l.c. on silica gel $G$ plates (Merck), activated at $120^{\circ} \mathrm{C}$ for $30 \mathrm{~min}$, with benzene-methanol-acetic acid (45:8:4, by vol.) or benzene-methanol $(19: 1, \mathrm{v} / \mathrm{v})$ or benzene-dioxanacetic acid (90:25:4, by vol.) as eluents. The radioactive areas were located by radioautography.

The residual hydrolysed urine after steam distillation was extracted with ether, and the extract was shaken successively with saturated aq. $\mathrm{NaHCO}_{3}$ and $1 \mathrm{M}-\mathrm{NaOH}$. The aqueous layers were acidified and re-extracted into ether and the extract was examined by g.l.c. and t.l.c. as described above. The residual urine was then made $5 \mathrm{M}$ with respect to $\mathrm{H}_{2} \mathrm{SO}_{4}$, boiled under reflux for $3 \mathrm{~h}$, and processed as described above.

In control experiments, it was established that no radioactivity was recovered as steam-volatile material when a solution of [U-14 C]phenylmercury acetate $(1 \mathrm{mg})$ in rat urine $(25 \mathrm{ml})$ was subjected to prolonged hydrolysis ( $3 \mathrm{~h}$ ) with $5 \mathrm{M}-\mathrm{H}_{2} \mathrm{SO}_{4}$.

Identification of mercury-containing metabolites. Urine and bile from rats dosed with $\left[\mathrm{U}-{ }^{14} \mathrm{C}\right]$ phenylmercury acetate were extracted with a solution of dithizone in chloroform (Daniel et al., 1971), and livers were extracted by the method of Tatton \& Wagstaffe (1969). The dithizonates were chromatographed on silica gel G (Daniel et al., 1971); the derivatives of phenylmercury, $o$-hydroxyphenylmercury and $p$-hydroxyphenylmercury were found to have $R_{F}$ values of $0.35,0.17$ and 0.12 respectively with hexane-acetone $(4: 1, v / v)$ as eluent.

Under these conditions $1 \mu \mathrm{g}$ of $o$ - or $p$-hydroxyphenylmercury is readily detectable as the coloured dithizonate.

Reverse isotope-dilution for phenol and quinol. Phenol $(200 \mathrm{mg})$ was added to two $20 \mathrm{ml}$ portions of $48 \mathrm{~h}$ urine; one was acidified with $\mathrm{H}_{2} \mathrm{SO}_{4}$ to $0.5 \mathrm{M}$ and boiled under reflux for $1 \mathrm{~h}$, and the other with $\mathrm{HCl}$ to $3 \mathrm{M}$ and boiled for $3 \mathrm{~h}$. The hydrolysed urine samples were steam distilled, the distillates were extracted with ether and the ether extract with $1 \mathrm{M}$ $\mathrm{NaOH}$. The toluene $p$-sulphonyl derivative of the phenol in the alkaline extracts was prepared and recrystallized from ethanol to constant specific radioactivity. Similar experiments were made with quinol added to $20 \mathrm{ml}$ urine samples; instead of steam distillation the hydrolysed urine was extracted directly with ether. The toluene $p$-sulphonyl derivative was recrystallized from ethanol-ethyl acetate $(1: 1, v / v)$.

Experiments in vitro. A $25 \%(\mathrm{w} / \mathrm{v})$ homogenate of rat liver in $0.1 \mathrm{M}$-sodium phosphate buffer, $\mathrm{pH7.4}$ was centrifuged at $12000 \mathrm{~g}$ for $20 \mathrm{~min}$. A $20 \mathrm{ml}$ portion of the supernatant $\left(F_{1}\right)$ was centrifuged at $200000 \mathrm{~g}$ to yield a microsomal fraction and a supernatant $\left(F_{3}\right)$. The microsomal fraction was resuspended in $20 \mathrm{ml}$ of buffer $\left(F_{2}\right)$. Preparation $F_{1}, F_{2}$ or $F_{3}(5 \mathrm{ml})$ in a final volume of $5.5 \mathrm{ml}$, either alone or with a NADPH-generating system $\left[\mathrm{MgCl}_{2}, 25 \mu \mathrm{mol}\right.$; nicotinamide, $15 \mu \mathrm{mol}$; glucose 6-phosphate (disodium salt), $40 \mu \mathrm{mol}$; $\mathrm{NADP}^{+}, 1.25 \mu \mathrm{mol}$; glucose 6 -phosphate dehydrogenase, $10 \mathrm{EC}$ units], was incubated with $\left[\mathrm{U}-{ }^{14} \mathrm{C}\right]$ phenylmercury acetate at $37^{\circ} \mathrm{C}$ with shaking in a flask sealed with a rubber diaphragm stopper. Portions of the liquid were taken at intervals for mercury analysis, and $1 \mathrm{ml}$ volumes of the vapour phase for g.l.c. The apparatus used was a Varian Aerograph Model 1522 with either a $6 \mathrm{ft} \times \frac{1}{8}$ in $(1.8 \mathrm{~m} \times$ $3 \mathrm{~mm})$ column of silicone $\mathrm{E} 301$ on Celite $(3: 7, \mathrm{w} / \mathrm{w})$ at $55^{\circ} \mathrm{C}$ and $\mathrm{N}_{2}$ at $20 \mathrm{ml} / \mathrm{min}$, or a $2 \mathrm{ft} \times \frac{1}{8}$ in $(60 \mathrm{~cm} \times$ $3 \mathrm{~mm})$ column of Porapak $Q\left(150-200\right.$ mesh) at $143^{\circ} \mathrm{C}$ and $\mathrm{N}_{2}$ at $50 \mathrm{ml} / \mathrm{min}$.

Three methods were used to measure the amount of mercury-free metabolites. (a) The supernatant $F_{3}$ was incubated with [U. $\left.{ }^{14} \mathrm{C}\right]$ phenylmercury acetate, and after acidification was extracted with toluene and washed with $1 \% \mathrm{Na}_{2} \mathrm{~S}$ solution to remove unchanged phenylmercury acetate (Gage, 1961). (b) Supernatant $\mathrm{F}_{3}$ was incubated with [U- $\left.{ }^{14} \mathrm{C}\right]$ phenylmercury acetate in a Cavette flask (Quickfit and Quartz Ltd., Stone, Staffs., U.K.) provided with a centre well containing $0.5 \mathrm{ml}$ of toluene. (c) Supernatant $F_{3}$ was incubated with $\left[\mathrm{U}-{ }^{14} \mathrm{C}\right]$ phenylmercury acetate in a bubbler tube 
which was connected in series with two bubblers containing $6 \mathrm{ml}$ of toluene scintillator solution [5-(4-biphenylyl)-2-(4-t-butylphenyl)-1-oxa-3,4-diazole (8g) in toluene (1 litre)] and $\mathrm{N}_{2}$ was passed through the train at $50 \mathrm{ml} / \mathrm{min}$. The radioactivity in the organic solution was measured in each of these procedures, and compared with the amount of inorganic mercury in the solution. In other experiments, the volatile metabolite obtained by method (c) was trapped in $\mathrm{CS}_{2}$ cooled in an ice-salt mixture, and the solvent was examined by g.l.c. as described above. These experiments were made with and without added NADH, and the mercury content of the solution was also measured before and after the aspiration period.

\section{Analytical methods}

The inorganic and total mercury content in urine and bile and in a $10 \%(w / v)$ homogenate of liver, kidney and faeces in aq. $1 \%$ sucrose were determined by the methods of Gage \& Warren (1970). Radioactivity was measured as described by Daniel $\&$ Gage (1965). Radioactivity in expired air before and after pyrolysis was determined as described by Daniel $e t$ al. (1971).

\section{Results}

\section{Excretion of radioactivity and mercury}

Table 1 shows that after a single subcutaneous dose of $\left[\mathrm{U}^{14} \mathrm{C}\right]$ phenylmercury acetate to rats, most of the radioactivity appeared in urine, with little in the faeces, but the major route of mercury excretion was through the faeces. The difference between total and inorganic mercury in urine on the first few days indicates a small excretion of organic mercury (about $2.5 \%$ of the dose); the low radioactivity of faeces indicates that most or all of the mercury in faeces was inorganic. At the end of this experiment $10.7 \%$ of the dose was found as inorganic mercury in the kidney and $2.9 \%$ in the liver, making the total recovery of mercury in the excreta and tissues ex- amined to be $78.7 \%$. No ${ }^{14} \mathrm{CO}_{2}$ was detected in the exhaled air in $48 \mathrm{~h}$. In a separate experiment, $5.5 \%$ of the radioactivity was excreted in $48 \mathrm{~h}$ as volatile material which was recovered as ${ }^{14} \mathrm{CO}_{2}$ after pyrolysis. The total excretion of radioactivity in urine, faeces and expired air was $94.1 \%$.

The biliary excretion of both radioactivity and mercury after a single subcutaneous dose of [U- $\left.{ }^{14} \mathrm{C}\right]-$ phenylmercury acetate was considerable (Table 2). Most of the mercury excreted during the first $48 \mathrm{~h}$ was organic; thereafter the proportion of organic mercury decreased.

\section{Accumulation in tissues}

After a single dose of phenylmercury acetate the mercury content of liver and kidneys increased over $24 \mathrm{~h}$ (Table 3); at $2 \mathrm{~h}$ more than half of this was organic, but at $24 \mathrm{~h}$ very little organic mercury remained.

\section{Identification of mercury-free metabolites in urine}

The distribution of radioactivity from the fractionation of hydrolysed urine is shown in Scheme 1. Phenol was identified in the steam distillates, which contained no other radioactive metabolites. The other fractions did not contain phenol and were too impure to be characterized by mass spectroscopy.

From the specific radioactivities of the toluene $p$-sulphonates isolated from hydrolysed urine to which phenol or quinol had been added, the percentage of radioactivity as phenol and quinol in the urine was calculated (Table 4).

\section{Identification of mercury compounds in urine, bile and liver}

Chromatography of the dithizone extracts of urine, bile and liver homogenates showed that inorganic mercury and phenylmercury were present. No trace of $o$ - or $p$-hydroxyphenylmercury could be detected.

Table 1. Excretion of radioactivity, inorganic and total mercury in urine and faeces

Results are shown for pooled excreta of five rats dosed with $2.95 \mathrm{mg}$ of $\left[\mathrm{U}^{-14} \mathrm{C}\right]$ phenylmercury acetate $/ \mathrm{kg}$ body wt.

Percentage of dose excreted

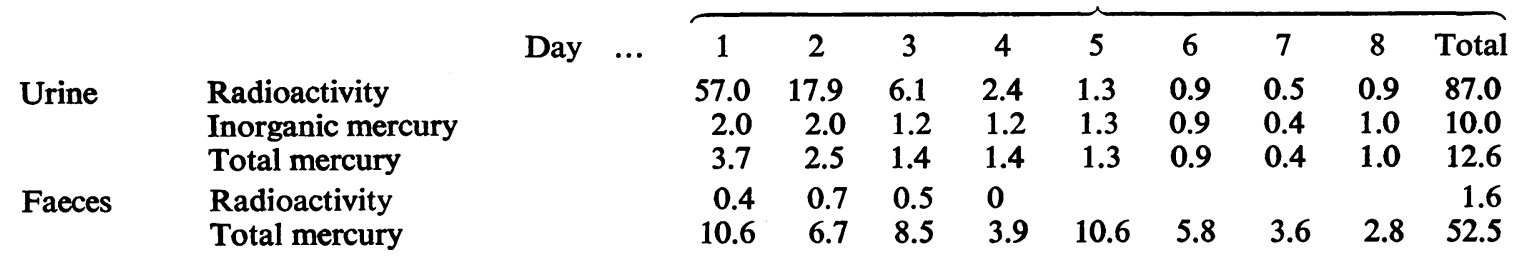

Vol. 129 
Table 2. Excretion of radioactivity, inorganic and total mercury in bile

Values are averages for three rats dosed with $3.75 \mathrm{mg}$ of $\left[\mathrm{U}-{ }^{14} \mathrm{C}\right]$ phenylmercury acetate/kg; ranges are given in parentheses.

\begin{tabular}{lcccccc} 
& & & \multicolumn{4}{c}{ Percentage of dose extracted } \\
\cline { 4 - 6 } Radioactivity & Day & $\ldots$ & 1 & 2 & 3 & 4 \\
Inorganic mercury & & & $12.7(11.4-14.9)$ & $9.5(8.7-10.6)$ & $2.8(2.0-4.1)$ & $0.9(0.5-1.4)$ \\
Total mercury & & & $2.2(1.3-3.4)$ & $5.8(4.6-7.4)$ & $4.1(3.4-4.7)$ & $3.8(3.2-4.4)$ \\
& & & $7.5(6.8-8.2)$ & $9.8(8.5-11.2)$ & $5.1(4.1-5.9)$ & $4.2(3.9-4.6)$ \\
\hline
\end{tabular}

Table 3. Total and inorganic mercury in liver and kidneys

Values are averages (in $\mu \mathrm{g} / \mathrm{g}$ ), with the range in parentheses, from groups of four rats dosed with $2.5 \mathrm{mg}$ of phenylmercury acetate/kg.

\begin{tabular}{|c|c|c|c|c|}
\hline \multirow{3}{*}{$\begin{array}{l}\text { Time after } \\
\text { injection (h) }\end{array}$} & \multicolumn{4}{|c|}{ Mercury in organ $(\mu \mathrm{g} / \mathrm{g})$} \\
\hline & \multicolumn{2}{|c|}{ Kidneys } & \multicolumn{2}{|c|}{ Liver } \\
\hline & Total & Inorganic & Total & Inorganic \\
\hline $\begin{array}{r}2 \\
6 \\
24\end{array}$ & $\begin{array}{c}7.1(6.2-8.3) \\
14.9(13.2-18.0) \\
22.4(21.6-23.5)\end{array}$ & $\begin{array}{c}2.9(2.3-3.3) \\
9.3(8.2-10.6) \\
17.9(17.0-19.7)\end{array}$ & $\begin{array}{l}1.9(1.4-2.5) \\
3.6(2.0-4.2) \\
7.4(5.5-9.8)\end{array}$ & $\begin{array}{l}0.5(0.4-0.8) \\
2.2(1.4-3.0) \\
5.6(3.9-7.6)\end{array}$ \\
\hline
\end{tabular}

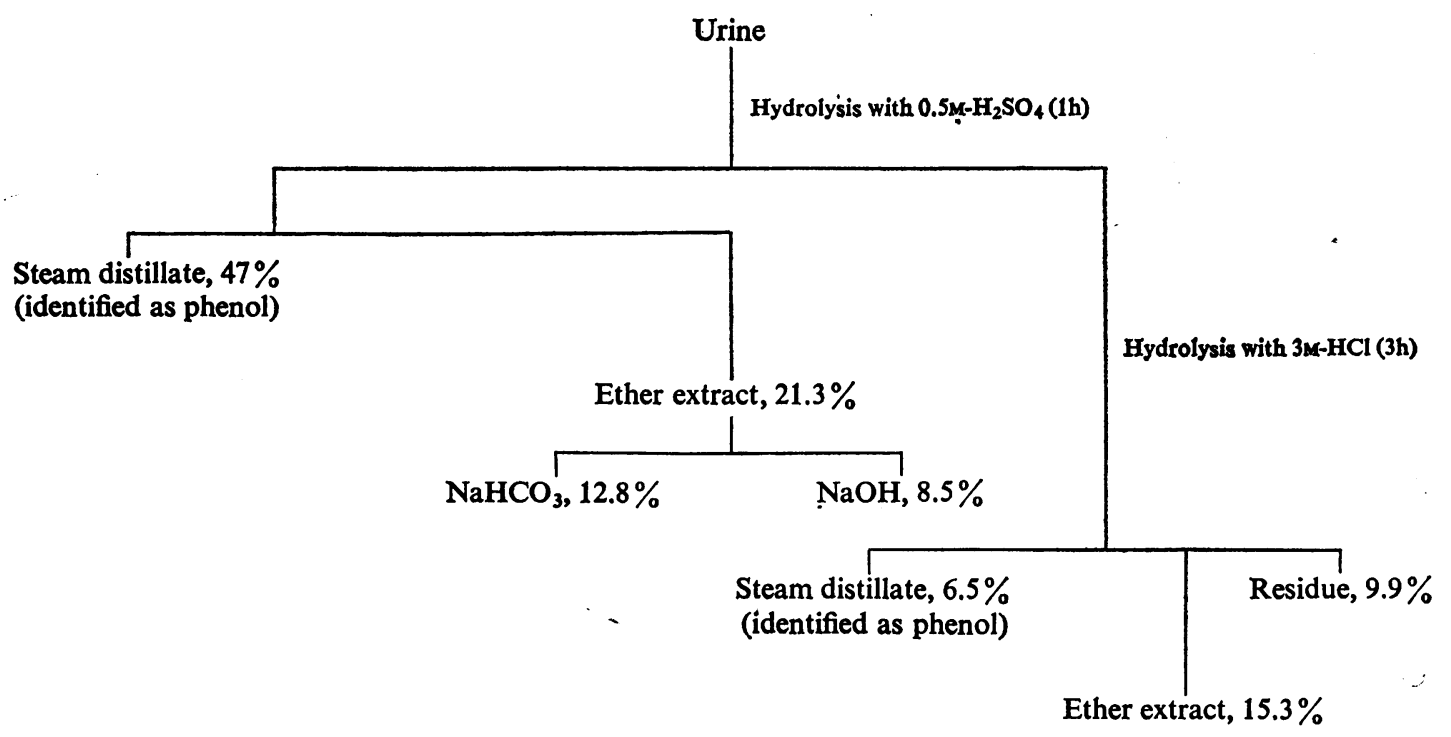

Scheme 1. Fractionation of hydrolysed urine from 20 rats dosed with $3.75 \mathrm{mg}$ of $\left[\mathrm{U}-{ }^{14} \mathrm{C}\right]$ phenylmercury acetate $/ \mathrm{kg}$ The percentage distribution of radioactivity in the various fractions is shown.

Breakdown of $\left[U-{ }^{14} C\right]$ phenylmercury acetate in rat liver homogenates

The release of mercury from phenylmercury acetate on incubation with subfractions of rat liver homogenates is shown in Table 5. These results show that the post-microsomal supernatant $\left(\mathrm{F}_{3}\right)$ was much more effective than the microsomal fraction, and that an NADPH-generating system was not necessary for this activity. There was some variation in activity with different liver preparations, but duplicate deter- 
Table 4. Phenol and quinol in urine determined by reverse isotope-dilution

Phenol or quinol $(200 \mathrm{mg}$ ) was added to hydrolysed urine of 20 rats dosed with $3.75 \mathrm{mg}$ of [U-14 C]phenylmercury acetate $/ \mathrm{kg}$, the toluene $p$-sulphonates isolated and their specific radioactivity measured.

\begin{tabular}{|c|c|c|c|c|}
\hline \multirow[b]{2}{*}{ Added } & \multirow[b]{2}{*}{ Hydrolysis } & \multirow[b]{2}{*}{ Fractionation } & \multicolumn{2}{|c|}{ Radioactivity } \\
\hline & & & $\%$ in urine & $\%$ of dose \\
\hline Phenol & $\begin{array}{l}0.5 \mathrm{M}-\mathrm{H}_{2} \mathrm{SO}_{4}, 1 \mathrm{~h} \\
3 \mathrm{M}-\mathrm{HCl}, 3 \mathrm{~h}\end{array}$ & Steam distillation & $\begin{array}{l}49.1 \\
50.5\end{array}$ & $\begin{array}{l}33.4 \\
34.3\end{array}$ \\
\hline Quinol & $\begin{array}{l}0.5 \mathrm{M}-\mathrm{H}_{2} \mathrm{SO}_{4}, 1 \mathrm{~h} \\
3 \mathrm{M}-\mathrm{HCl}, 3 \mathrm{~h}\end{array}$ & Ether extraction & $\begin{array}{l}2.6 \\
3.7\end{array}$ & $\begin{array}{l}1.8 \\
2.5\end{array}$ \\
\hline
\end{tabular}

Table 5. Release of $\mathrm{Hg}^{2+}$ from phenylmercury acetate by rat liver homogenate fractions

Fractions: $F_{1}, 12000 \mathrm{~g}$ supernatant; $F_{2}$, microsomal fraction; $F_{3}, 200000 \mathrm{~g}$ supernatant. Experimental details are given in the Materials and Methods section.

$\begin{array}{ccccc}\text { Fraction } & \begin{array}{c}\text { Concn. of } \\ \text { phenylmercury acetate } \\ (\mu \mathrm{g} / \mathrm{ml})\end{array} & \begin{array}{c}\text { Incubation time } \\ (\mathrm{min})\end{array} & \begin{array}{c}\text { NADPH-generating } \\ \text { system }\end{array} & \begin{array}{c}\% \text { of } \mathbf{H g}^{2+} \\ \text { released }\end{array} \\ \mathrm{F}_{1} & 3.64 & 90 & + & 11.9 \\ & 3.64 & 120 & + & 20.1 \\ \mathrm{~F}_{2} & 3.64 & 120 & - & 8.0 \\ & 3.64 & 90 & + & 4.1 \\ \mathrm{~F}_{3} & 6.30 & 120 & + & 6.3 \\ & 19.3 & 90 & - & 21.2 \\ & 33.3 & 120 & - & 18.4 \\ & 33.3 & 90 & + & 14.2,14.0 \\ & 4.0 & 90 & + & 17.9 \\ & 6.3 & 90 & + & 18.1,21.2\end{array}$

minations on the same preparation were reasonably close.

Tests were made with the supernatant layer $\left(\mathrm{F}_{3}\right)$ to compare the release of inorganic mercury with the production of a mercury-free radioactive metabolite. The results in Table 6 show that reasonably good agreement was obtained when the radioactive metabolite was separated by solvent extraction, by diffusion into toluene, or by aspiration into toluene scintillator.

\section{Identification of metabolites obtained in vitro}

When phenylmercury acetate $(40 \mu \mathrm{g} / \mathrm{ml})$ was incubated with the rat liver supernatants $F_{1}$ and $F_{3}$ $(23 \mathrm{ml})$, g.l.c. analysis of the vapour phase above the liquid in the reaction flask gave peaks with retention times identical with those of benzene with the two columns used. When phenylmercury acetate was incubated with supernatant $F_{3}$ and the volatile metabolite aspirated with $\mathrm{CS}_{2}$ by method (c) above, benzene was the only component detected in the $\mathrm{CS}_{2}$ by g.l.c. and the amount released was approximately equal to the amount of mercuric ion released (Table 7). The aspiration procedure did not result in any loss of mercury from the solution.

\section{Discussion}

The results show that when [U- $\left.{ }^{14} \mathrm{C}\right]$ phenylmercury acetate is administered to the rat, it is rapidly metabolized to inorganic mercury and conjugated phenol, with a small proportion of the conjugates of quinol. A little unchanged phenylmercury is excreted in urine during the first few days after the dose. The relative amounts of phenol obtained from urine by hydrolysis with $0.5 \mathrm{M}-\mathrm{H}_{2} \mathrm{SO}_{4}$ and $3 \mathrm{M}-\mathrm{HCl}$ suggests that most of the phenol is excreted as the sulphate with a minor amount as the glucuronide. The amount of organic mercury in the liver and kidneys remains fairly constant during 2-24h after dosing, but the amount of inorganic mercury in the kidneys rises rapidly (Table 3). This suggests that phenylmercury is broken down in the tissues and the inorganic mercury

Vol. 129 
Table 6. Release of $\mathrm{Hg}^{2+}$ and radioactive metabolites from $\left[U-{ }^{14} \mathrm{C}\right]$ phenylmercury acetate in vitro

$\left[{ }^{14} \mathrm{C}\right]$ Phenylmercury acetate was incubated with rat liver supernatant (fraction $\mathrm{F}_{3}$ ); methods used to separate the radioactive metabolites are described in the Materials and Methods section.

\begin{tabular}{|c|c|c|c|c|}
\hline \multirow{2}{*}{ Method } & \multirow{2}{*}{$\begin{array}{c}\text { Vol. of } \\
F_{3} \text { supernatant } \\
(\mathrm{ml})\end{array}$} & \multirow{2}{*}{$\begin{array}{c}\text { Concn. of } \\
{\left[\mathrm{U}-{ }^{14} \mathrm{C}\right] \text { phenylmercury }} \\
\text { acetate } \\
(\mu \mathrm{g} / \mathrm{ml})\end{array}$} & \multicolumn{2}{|c|}{$\%$ Breakdown } \\
\hline & & & $\mathbf{H g}^{2+}$ & Radioactivity \\
\hline \multirow{3}{*}{$\begin{array}{l}\text { Solvent extraction } \\
\quad \text { (Gage, 1961) }\end{array}$} & 15 & 35 & 18.4 & 18.8 \\
\hline & 15 & 35 & 12.4 & 11.3 \\
\hline & 11.5 & 45 & 8.8 & 9.5 \\
\hline $\begin{array}{l}\text { Collection in toluene in } \\
\text { Cavette flask (cor- } \\
\text { rected for } 85 \% \text { re- } \\
\text { covery of [U-14 C]- } \\
\text { benzene) }\end{array}$ & 15 & 33 & 7.0 & 6.6 \\
\hline \multirow{2}{*}{$\begin{array}{l}\text { Aspiration through } \\
\text { toluene scintillator }\end{array}$} & 14 & 36 & 17.2 & 13.7 \\
\hline & 11 & 45 & 5.2 & 4.2 \\
\hline
\end{tabular}

Table 7. Release of $\mathrm{Hg}^{2+}$ and benzene from phenylmercury acetate in vitro

Phenylmercury acetate $(0.5 \mathrm{mg})$ was incubated with $10 \mathrm{ml}$ of supernatant $\mathrm{F}_{3}$ for $2 \mathrm{~h}$ at $37^{\circ} \mathrm{C}$, and the volatile metabolite was collected in $2 \times 6 \mathrm{ml}$ of chilled $\mathrm{CS}_{2}$. The results are percentages of phenylmercury acetate broken down. In Expt. I the $\mathrm{Hg}^{2+}$ was measured before and after aspiration; in Expt. II both $\mathrm{Hg}^{2+}$ and benzene were measured. The results for benzene were corrected for a recovery of $76.5 \%$, found by experiments with benzene alone.

\begin{tabular}{|c|c|c|c|c|}
\hline & \multicolumn{4}{|c|}{ Phenylmercury acetate broken down ( $\%)$} \\
\hline & \multicolumn{2}{|c|}{ Expt. I } & \multicolumn{2}{|c|}{ Expt. II } \\
\hline & $\begin{array}{c}\mathrm{Hg}^{2+} \text { before } \\
\text { aspiration }\end{array}$ & $\begin{array}{l}\mathrm{Hg}^{2+} \text { after } \\
\text { aspiration }\end{array}$ & $\mathrm{Hg}^{2+}$ & Benzene \\
\hline No NADH & $\begin{array}{l}20.6 \\
22.9 \\
24.4\end{array}$ & $\begin{array}{l}20.6 \\
21.8 \\
22.7\end{array}$ & $\begin{array}{l}56.6 \\
35.2 \\
32.4\end{array}$ & $\begin{array}{l}57.9 \\
35.0 \\
25.4\end{array}$ \\
\hline With $0.1 \mathrm{~mm}$-NADH & $\begin{array}{l}22.4 \\
25.9\end{array}$ & $\begin{array}{l}23.7 \\
24.4\end{array}$ & $\begin{array}{l}19.0 \\
16.8\end{array}$ & $\begin{array}{l}24.8 \\
22.0\end{array}$ \\
\hline
\end{tabular}

migrates to the kidneys; this is confirmed by the observations of those investigators who have studied the distribution and excretion of radioactivity after administration of phenyl[ $\left.{ }^{203} \mathrm{Hg}\right]$ mercury acetate.

A considerable proportion of the dose is excreted as phenylmercury in bile, though less than was observed with methoxyethylmercury (Daniel et al., 1971). As the biliary excretion is more rapid than the faecal excretion, and no radioactivity was found in faeces, the phenylmercury must be partly resorbed and partly degraded in the gut. This ready biliary excretion of phenylmercury can account for the intestinal and faecal radioactivity observed by Berlin
\& Ullberg (1963) and Ellis \& Fang (1967) using phenyl $\left[{ }^{203} \mathrm{Hg}\right]$ mercury acetate. After the administration of $\left[\mathrm{U}-{ }^{14} \mathrm{C}\right]$ phenylmercury acetate, bile contains more radioactivity than can be accounted for by the phenylmercury present (Table 2), so a mercury-free metabolite must be excreted by this route, presumably phenyl glucuronide.

On the basis of the experiments demonstrating the excretion of conjugated phenol after the administration of phenylmercury acetate, Daniel \& Gage (1971) proposed the hypothesis that phenylmercury is hydroxylated by the microsomal fraction to give $p$-hydroxyphenylmercury, which, according to 
Wiener et al. (1962), is unstable in the presence of cysteine at low $\mathrm{pH}$ values, and that fission of the carbon-mercury bond in vivo might not therefore involve an enzyme system. It now seems certain that this hypothesis is not correct, as attempts to demonstrate the presence of $o$ - or $p$-hydroxyphenylmercury in urine and bile have proved negative, and the release in vitro of inorganic mercury by liver homogenates is effective in the absence of the microsomal fraction. The evidence now shows that benzene is the primary metabolite; this is then converted by microsomal hydroxylation into phenol with a minor amount of quinol, which are excreted as conjugates. This conforms with the metabolic pathway of benzene in the rabbit found by Parke \& Williams (1953).

Furukawa et al. (1969) and Tonomura \& Kanzaki (1969) have shown that a cell-free extract of a mercury-resistant pseudomonad is capable of splitting phenylmercury into benzene and metallic mercury. They claim that this reaction requires NADH, or an NADH-generating system, and thioglycollate. Our results have shown that breakdown of phenylmercury by a liver preparation does not require NADH and that no volatilization of metallic mercury occurs with or without added NADH. This breakdown to benzene and mercuric ion can be represented by the addition of a proton:

$$
\mathrm{C}_{6} \mathrm{H}_{5} \mathrm{Hg}^{+}+\mathrm{H}^{+}=\mathrm{C}_{6} \mathrm{H}_{6}+\mathrm{Hg}^{2+}
$$

[Although phenylmercury acetate is stable in weakly acid solutions in the presence of cysteine at $37^{\circ} \mathrm{C}$ (Wiener et al., 1962), mercuric ions are readily liberated when the solution is boiled for $1 \mathrm{~h}$ (Gage \& Warren, 1970).] The reaction in vivo can be regarded as a hydrolysis, rather than the reduction proposed by Tonomura \& Kanzaki (1969). It is possible that different mechanisms operate in the two systems, but an alternative explanation is that in both, mercuric ion is first produced, and that in the microbiological preparation this is rapidly reduced to elemental mercury by an enzyme requiring NADH. Magos et al. (1964) showed that some micro-organisms, including Pseudomonas aeruginosa, could convert mercuric ion into metallic mercury.
The mechanism of the reaction identified in this present study clearly requires further investigation. Apart from phenylmercury acetate, inorganic mercury is also released when either methoxyethylmercury chloride or $p$-chloromercuribenzoate, but not methylmercury or ethylmercury salts, are incubated with supernatant $F_{3}$.

We acknowledge the assistance of Mr. G. H. Walker, who synthesized $\left[\mathrm{U}-{ }^{14} \mathrm{C}\right]$ phenylmercury acetate and the two hydroxyphenylmercury derivatives.

\section{References}

Berlin, M. \& Ullberg, S. (1963) Arch. Environ. Health 6, 602-609

Daniel, J. W. \& Gage, J. C. (1965) Food Cosmet. Toxicol. 3, 405-415

Daniel, J. W. \& Gage, J. C. (1971) Biochem. J. 122, 24P

Daniel, J. W., Gage, J. C. \& Lefevre, P. (1971) Biochem. J. 121, 411-415

Ellis, R. W. \& Fang, S. C. (1967) Toxicol. Appl. Pharmacol. 11, 104-113

Friberg, L., Odeblad, E. \& Forssman, S. (1957) AMA Arch. Ind. Health 16, 163-168

Furukawa, K., Suzuki, T. \& Tonomura, K. (1969) Agr. Biol. Chem. 33, 128-130

Gage, J. C. (1961) Analyst (London) 86, 457-459

Gage, J. C. (1964) Brit. J. Ind. Med. 21, 197-202

Gage, J. C. \& Swan, A. A. B. (1961) Biochem. Pharmacol. 8,77

Gage, J. C. \& Warren, J. M. (1970) Ann. Occup. Hyg. $73,115-123$

Magos, L., Tuffery, A. A. \& Clarkson, T. W. (1964) Brit. J. Ind. Med. 21, 294-298

Miller, V. L., Klavano, P. A. \& Csonka, E. (1960) Toxicol. Appl. Pharmacol. 2, 344-352

Parke, D. V. \& Williams, R. T. (1953) Biochem. J. 54, 231-238

Swensson, A., Lundgren, K. D. \& Lindström, O. (1959) AMA Arch. Ind. Health 20, 432-443

Tatton, J. O’G. \& Wagstaffe, P. J. (1969) J. Chromatogr. $44,284-289$

Tonomura, K. \& Kanzaki, F. (1969) Biochim. Biophys. Acta 184, 227-229

Ulfvarson, U. (1962) Int. Arch. Gewerbepathol. Gewerbehyg. 19, 412-422

Wiener, I. M., Levy, R. I. \& Mudge, G. H. (1962) J. Pharmacol. Exp. Ther. 138, 96-112 